\title{
Reflexões sobre os sistemas categoriais de Aristóteles, Kant e Ranganathan
}

\author{
Michel Maya Aranalde \\ Bacharel e licenciado em filosofia e bacharel em biblioteconomia pela UFRGS. Bibliotecário-documentalista da Biblioteca Setorial de \\ Ciências Sociais e Humanidades da UFRGS. \\ E-mail: 00097178@ufrgs.br
}

\section{Resumo}

Este trabalho apresenta a teoria das categorias conforme elaboradas por Aristóteles, Kant e Ranganathan. Procura subsídios que permitam identificá-las como princípios fundamentais e imprescindíveis para a organização do conhecimento. As três perspectivas são confrontadas para estabelecer as diferenças e semelhanças, tendo em vista os objetivos de cada sistema categorial. Conclui que Aristóteles concebe seus princípios fundamentais para expressarem os modos do ser, ao passo que Kant os relaciona como modos do pensar. Por sua vez, Ranganathan formula as categorias como modos de classificar.

\section{Palavras-chave}

Categorias. Classificação filosófica. Teoria da classificação facetada. Organização do conhecimento.

\section{Reflections on the categorical systems of Aristotle, Kant and Ranganathan}

\begin{abstract}
This paper presents the theory of the categories as developed by Aristotle, Kant and Ranganathan. Subsidies are sought for in order to identify them as fundamental and essential principles for organization of knowledge. Three perspectives are confronted for establishing the differences and similarities in view of the objectives of each categorical system. The conclusion is that Aristotle conceives his principles as fundamental for expressing the ways of being, whereas Kant lists them as ways of thinking. In his turn, Ranganathan formulates the categories as ways of classifying.
\end{abstract}

\section{Keywords}

Categories. Phylosophycal classification. Faceted classification theory. Organization of knowledge. 


\author{
O que chamamos princípio é quase sempre o fim \\ $e$ alcançar o fim é alcançar um princípio. \\ Qualquer ação é um passo rumo ao todo, ao fogo, \\ uma descida à garganta do mar \\ ou à pedra indecifrável - e dai é que partimos.
}

Thomas Stearns Eliot

\section{INTRODUÇÃO}

Conhecer e reconhecer o mundo circundante, as relações e interações estabelecidas ou por estabelecer com ele constituem aspirações essencialmente humanas. Desde os primórdios, o ser humano cria sistemas de símbolos como instrumentais que lhe permitam entender sua posição e papel no mundo, refletindo sobre suas experiências, buscando interpretá-las, compreendêlas e, desta forma, articular, organizar, sintetizar e universalizar o conhecimento extraído delas.

A gestão de informações se caracteriza, entre outras atividades igualmente importantes, pela reflexão sobre formas de ordenar o conhecimento. Assim, um dos seus focos de atenção recai exatamente sobre o problema da classificação e organização do saber registrado em seus mais variados tipos de suportes, pois é necessário identificar, selecionar e disponibilizar o patrimônio intelectual da humanidade de modo organizado e preciso.

De maneira simplificada, pode-se dizer que classificar significa identificar entidades, reunindo as semelhantes, separando as diferentes e, por meio deste processo, organizá-las. Esta organização, é claro, não ocorre espontaneamente, mas vem primeiro através do pensamento, tendo sua consecução na forma de uma ação racional. Nesse processo intelectual, as categorias são concebidas como elementos possibilitadores de sua plena efetivação.

As categorias são identificadas como conceitos elementares, isto é, como princípios que permitem identificar as notas essenciais que caracterizam um objeto do conhecimento. A partir desta operação mental de identificação, é possível formular conceitos empíricos, ou seja, buscar uma equivalência entre como o objeto se apresenta e a representação mental que se faz dele e de suas relações com outros objetos. As categorias são concebidas como metaconceitos que permitem a efetiva conceitualização de objetos passíveis de serem conhecidos, organizados e classificados. Portanto, elas são elementos intermediários entre os conceitos e a realidade cognoscível.

Formular representações do conhecimento é uma capacidade de que o pensamento humano dispõe para organizar e classificar a realidade. Este processo inicia pelo uso de categorias, as quais são expressões lógico-linguísticas de determinada juntura da realidade; o uso de tais expressões possibilita ordenar as informações referentes aos diversos modos como a compreendemos. Com isto, as categorias se apresentam como instrumentos imprescindíveis para orientar as ações dos profissionais que trabalham com a organização da informação.

Partindo destes pressupostos pretende-se, com este artigo, contribuir para uma reflexão sobre o processo de organização das informações tendo o foco direcionado para as categorias caracterizadas como os princípios classificatórios que possibilitam a consecução desta tarefa. Para tanto, procura-se estabelecer relações entre as categorias apresentadas em dois sistemas filosóficos de classificação - o aristotélico e o kantiano -, juntamente com as categorias formuladas pelo bibliotecário indiano Shiyali Ramamrita Ranganathan para orientar a identificação, classificação e organização do conhecimento registrado.

\section{O CONTEXTO DO ESTUDO}

A escolha dos autores abordados neste artigo se pautou por dois motivos básicos. O primeiro diz respeito ao fato de os três pensadores estarem envolvidos com práticas biblioteconômicas. O segundo motivo está relacionado à constatação 
de que os autores elaboraram formulações teóricas reconhecidamente relevantes que indicam as categorias como princípios básicos e essenciais para a organização do conhecimento.

Pioneiro na apresentação de um sistema categorial, Aristóteles nasceu no primeiro ano da $99^{a}$ olimpíada (384a.C) ${ }^{1}$ em Estagira, situada na costa oriental da Macedônia, à época colônia setentrional da Grécia. $\mathrm{Na}$ adolescência, partiu rumo a Atenas para estudar com Platão na Academia, sendo chamado por ele de "o leitor" pelos "[...] hábitos do estagirita de ler e pesquisar as obras científico-literárias diretamente nos textos que compunham a tradição helênica [...]" (BITTAR, 2003, p. 18).

Zingano reafirma este testemunho e o complementa ao destacar que:

[...] Aristóteles estudava tanto que foi apelidado, já nos tempos da Academia, de o leitor. Aristóteles lia, e muito, pois em todas as suas obras demonstra um grande conhecimento dos pensadores que o precederam; foi ele também, segundo alguns testemunhos, quem por primeiro constituiu uma biblioteca, e com base em suas práticas foi criada a famosa Biblioteca de Alexandria (ZINGANO, 2002, p. 29 - grifo do autor).

$\mathrm{O}$ autor reconhece que os indícios deste feito não podem se constituir como fato inquestionável, mas são muito verossímeis. O fato é que, mais tarde, Aristóteles fundou o Liceu, sua própria escola, destacando-se, entre outras atividades, pelas estratégias que desenvolveu para definir e organizar o saber existente, elaborando refinado sistema de organização do conhecimento.

Outro especialista em Aristóteles endossa este ponto ao salientar que no Liceu também se realizavam pesquisas científicas. Ademais, foi o local em que se reuniu material que deu origem a

\footnotetext{
${ }^{1}$ Cauquelin (1995) indica que a cultura helênica estabeleceu um sistema de medida de tempo em que a noção básica era a Olimpíada. Cada uma correspondia ao período de quatro anos, representando o intervalo de tempo entre dois jogos olímpicos.
}

[...] uma importante biblioteca. Assim, uma das atividades mais destacadas dos membros do Liceu consistia em reunir informações de todos os ramos do saber (PELLEGRIN, 2006, p. 18).

O estagirita, a partir de sua concepção enciclopédica do saber, foi o responsável pela identificação de vários ramos da ciência e de seus objetos de estudo, com imensa produção intelectual que gerou "[...] entre outras coisas, até mesmo um lugar para estocar tanta engenhosidade e criatividade: a biblioteca." (ZINGANO, 2005, p. 67). Os estudos do filósofo grego abrangeram os mais diferentes temas, com impressionante perspicácia. Fonseca (2005, p. 80) afirma ser plausível

[...] supor que nenhum outro pensador, em qualquer tempo, tenha chegado a saber e sistematizar uma proporção tão vasta de tudo o que havia para se saber em sua época.

Immanuel Kant, por sua vez, nasceu em 1724 na cidade de Königsberg, Prússia Oriental, atualmente denominada Kaliningrado, nunca tendo de lá se afastado. Apesar da extrema pobreza de sua família, dedicou-se aos estudos de modo exemplar, ingressando no seleto círculo universitário aos 16 anos, de onde seguiu a carreira acadêmica.

Segundo Caygill (2000b, p. 40), o pensador alemão exerceu atividades adicionais "[...] como a de subdiretor da Biblioteca Real e a de curador de uma coleção particular de história natural.". O autor citado informa ainda que essa atividade rendeu a Kant o seu primeiro salário anual integral e pagamentos em espécie: trigo, cerveja e lenha. Afora isto, pode-se dizer que, além de exercer funções de bibliotecário, o filósofo foi docente privado, isto é, professor particular para os filhos das famílias mais abastadas.

O último dos três pensadores aqui estudados, Shiyali Ramamrita Ranganathan, nasceu em 1892, na pequena aldeia de Shialy, na Índia meridional. Foi acima de tudo um estudioso: bacharel e mestre em matemática pelo Madras Christian College, diplomou-se ainda como professor de língua 
inglesa, lecionando em diversos colégios de Madras. Chamado para exercer as funções de bibliotecário da Madras University, foi submetido ao que hoje chamaríamos de uma especialização em biblioteconomia em prestigiada universidade inglesa.

Os períodos de estudos na Inglaterra e a própria prática profissional the permitiram refletir sobre os problemas enfrentados pelos bibliotecários na tarefa de organizar o conhecimento registrado. As reflexões dele se cristalizam, como bem salienta Vickery (1980), nos maiores desenvolvimentos teóricos apresentados para a teoria da classificação do século 20. A contribuição do bibliotecário indiano é fruto de longo estudo frequentemente reformulado e aprimorado, resultando que tanto seu esforço intelectual, quanto os resultados reconhecidamente importantes a que chegou o apontam como o grande teórico da biblioteconomia e da ciência da informação, sendo considerado internacionalmente como o introdutor do método científico nesses ramos do conhecimento.

A concepção dos pensadores sobre as categorias será apresentada na sequência do artigo. No entanto, é importante destacar que a análise das três concepções não pretende constituir uma produção filosófica, mas sim uma reflexão e uma tentativa de identificar problemas, soluções e perspectivas envolvidas na classificação e na organização do conhecimento. Assim, tem-se em vista oferecer ao profissional da informação uma visão ampla deste processo, permitindo perceber o que há de primordial nos respectivos sistemas e nos esforços dos autores aqui abordados em cumprir seus objetivos.

\section{CATEGORIAS}

De forma bem abrangente, categoria designa

[...] em geral, qualquer noção que sirva como regra para a investigação ou para sua expressão linguística em um campo qualquer (ABBAGNANO, 1974, p. 147).

Poderíamos completar a frase com a expressão "do conhecimento", tendo em vista que as categorias, como objeto de estudo deste artigo, são concebidas como conceitos mais elementares a partir dos quais se podem formar outros conceitos.

As categorias se constituem como condição de possibilidade para certos juízos básicos que emitimos sobre o mundo na tentativa de interpretálo e compreendê-lo. Elas permitem descrever o mundo e as coisas que o compõem. Partindo de tal perspectiva, podem ser compreendidas como unidades cognitivas que guiam a apreensão da multiplicidade, pois é sob tais unidades que distinguimos e classificamos os vários modos em que o ser se apresenta, operando a separação, a conjunção e a classificação do variegado de seres que preenche o mundo.

A classificação revela um processo da mente que busca agrupar as coisas conforme seus graus de semelhança e separá-las conforme seus graus de dessemelhança, sendo ela inerente ao modo como o ser humano se coloca no mundo para tentar compreendê-lo. Isto posto, é necessário ressaltar a importância de categorizar e de classificar para o viver humano. Nas palavras de Dewey:

Classificar é, na verdade, tão útil quanto natural. A multidão indefinida de eventos particulares e mutáveis é enfrentada pela mente como atos de definição, inventariação, listagem, redução a verbetes comuns e separação em grupos (1922, apud CASSIRER, 1994). ${ }^{2}$

Ora, se classificar pressupõe categorizar, as categorias enquanto elementos imprescindíveis para a classificação são as maneiras como se pode identificar e falar das coisas, possibilitando a elaboração de classes mais gerais em que são ordenados os seus predicados. A formação destas classes gerais pressupõe a delimitação das notas características das coisas, isto é, de traços fixos, mediante os quais elas podem ser reconhecidas como semelhantes ou dessemelhantes, coincidentes

${ }^{2}$ DEWEY, John. Human, Nature and Coduct. New York: Holt \& Co., 1922, p. 131 apud CASSIRER, Ernst. Ensaio sobre o Homem: introdução a uma filosofia da cultura humana. São Paulo: Martins Fontes, 1994, p. 113-4. 
ou não coincidentes, possibilitando reuni-las em uma classe similar, separando as distintas e as distribuindo em outras classes. É exatamente isto que as categorias permitem: dizer o que é e o que não é.

As categorias são apresentadas neste trabalho segundo a definição oferecida por Caygill (2000a, p. 50 - grifos do autor) como "as formas de acordo com as quais os objetos de experiência são estruturados e ordenados. O termo grego clássico Kategorein significava 'acusar', 'dizer de' ou 'julgar' [...]". Assim, as categorias são caracterizadas como recortes que o pensamento humano faz da realidade, sendo um produto lógico, isto é, um produto do pensamento e de sua expressão: a linguagem. Como unidades cognitivas, elas são, portanto, princípios fundamentais para os processos intelectuais de identificar, entender e organizar as coisas do mundo. Como explicita Shera (1969, p. 42 - grifos do autor):

A análise em qualquer nível traz à baila certas 'noções específicas' que constituem o fundo de todo pensamento, e muito antes de estar o indivíduo cônscio destas ideias como fatos em si próprios, ele as empregará no seu pensamento. Resumindo, pensa-se mediante categorias muito antes de pensar sobre elas. Uma das preocupações da lógica é revelar estas 'noções específicas', isolá-las e identificá-las como 'categorias' para que possam ser transformadas em objetos de estudo intrínseco e em instrumentos úteis a qualquer processo de classificação.

O primeiro trabalho sistemático de elaboração e de abordagem de categorias para a organização do conhecimento nos foi oferecido por Aristóteles, como será apresentado na sequência. Após a importante identificação das categorias como instrumentos para conhecimento do mundo, esta concepção caiu gradualmente em desuso. Muito disto se deve à tentativa dos pensadores medievais, profundos conhecedores da filosofia grega, de tentar adequar e reconciliar a terminologia aristotélica à escolástica. É bem verdade que diversos estudiosos medievais interpretaram e reformularam as categorias aristotélicas, concebendo-as como 'gêneros supremos' e oferecendo importantes subsídios para a reflexão filosófica.

Entretanto, coube ao filósofo alemão Immanuel Kant efetuar o resgate de tais categorias e salientar a importância delas. Ressalta Caygill (2000b, p. 11) que o filósofo

[...] deu um grande passo reintroduzindo na terminologia filosófica alemã uma série de palavras e conceitos gregos que haviam caído em desuso, como categoria [...].

O ponto de Kant em seu resgate é demonstrar que a elaboração de categorias para explicar o pensamento humano se reveste de autoridade por si só, não constituindo, absolutamente, uma posição arbitrária. Kant se dedica a rever a formulação aristotélica das categorias, reelaborálas, justificá-las e apresentá-las em uma tábua de categorias em que elas se relacionam reciprocamente e adquirem sentido.

O bibliotecário indiano Ranganathan, por seu turno, concebe e elabora as categorias em sentido bastante restrito, mas não menos importante: no âmbito de identificação, classificação e organização dos registros produzidos pelos seres humanos em suas atividades teóricas e práticas. Esclarece Souza (1998) que o objetivo específico e justificadamente pragmático das categorias ranganathianas é oferecer bases para certo tipo de organização do conhecimento.

Ranganathan concebe que apenas uma classificação dos registros humanos pode e deve ser feita para atender a todos os propósitos. Para efetuar esta tarefa, indica que qualquer assunto a ser classificado será sempre a manifestação de cinco categorias básicas ou fundamentais, caracterizadas como conceitos de alta generalidade e larga aplicação, os quais servem de estrutura a um esquema de classificação, pois sob eles se podem reunir outros conceitos. 
Por causa das características anteriormente abordadas, as categorias fundamentais podem ser aplicadas à classificação do conhecimento existente. Além disto, possibilitam a criação de ferramentas destinadas a resolver os problemas enfrentados nos processos de produção, representação e organização do conhecimento, como os tesauros e sistemas de classificação documentária.

\section{Concepção aristotélica}

A organização do conhecimento sempre foi uma preocupação do ser humano. As tentativas de resolução dos problemas surgidos na sua realização deram origem a diversos sistemas de classificação apresentados como instrumentos auxiliares para efetivação desta grandiosa e difícil tarefa. Os registros humanos atribuem ao estagirita Aristóteles, influenciado por seu mestre Platão, a primeira abordagem relacionada ao tema.

Salienta Vickery (1980, p. 188) que o sistema de classificação elaborado pelo filósofo “[...] foi a estrutura do conhecimento por aproximadamente dois mil anos [...]", servindo de modelo para muitos sistemas de classificação e sendo adaptado conforme os pressupostos básicos e objetivos de cada um dos novos sistemas desenvolvidos desde então.

O sistema aristotélico de classificação surgiu pela necessidade de abarcar e expressar a realidade de modo organizado e preciso. Para isto, tal sistema buscou a identificação e o estabelecimento de conceitos básicos que orientassem os agrupamentos e as partições do real operado pelo pensamento humano, ou seja, de categorias primordiais. Esse trabalho do filósofo grego, no que se refere à função das categorias na organização e na classificação do conhecimento existente, mostra-se, ainda hoje, como importante objeto de estudo para fundamentar e compreender a teoria da classificação.

A classificação embasada pelas categorias elaboradas por Aristóteles busca responder à questão sobre o que há no mundo. Entretanto, não se trata simplesmente de inventariar as coisas que estão ao redor, pois

[...] o que se quer saber é quais são os elementos básicos ou primordiais do mundo, aquilo do qual tudo o mais é feito e no qual tudo um dia se dissolve (ZINGANO, 2002, p. 29).

No sistema aristotélico, as categorias servem de fundamento ao conhecimento das coisas. Elas são os princípios básicos que tornam o conhecimento possível, partindo de uma perspectiva que concebe o mundo como um todo integrado de causas e efeitos, em que as coisas e as suas propriedades essenciais, seus estados, processos e relações podem e devem ser reveladas pelo trabalho intelectual.

Desta perspectiva, utilizar as categorias é identificar unidades básicas de sentido. Essas unidades permitem apreender conceitualmente os objetos e dar definições deles. Assim, Aristóteles estabelece unidades conceituais capazes de dar conta da diversidade e da multiplicidade que o mundo apresenta. O ser não segue um só registro, mas se cinde em diferentes tipos de 'gêneros supremos', ou seja, em categorias. A categoria primordial é a da 'substância', à qual as demais fazem referência.

No tocante à apresentação aristotélica, será utilizada principalmente a Metafísica (1998), pois, apesar de as categorias serem apresentadas também na obra denominada Categories (1995) - Tratado das Categorias, a última é motivo de disputa entre os especialistas na área. Mansion (2005) indica que esse tratado é uma obra de autenticidade discutível e que o número das categorias não está fixo.

Driscoll (2005), por sua vez, acredita na autenticidade do Tratado das Categorias, mas concede que é uma obra da juventude do pensador, enquanto a Metafísica é uma obra indubitavelmente madura do filósofo grego. O fato é que Aristóteles apresenta as categorias em número de oito na Física e na Metafísica, ao passo que, no Tratado das Categorias, apresenta em número de dez. Sem entrar diretamente na disputa, optou-se pela apresentação feita na Metafísica. 
Aristóteles anuncia que "[...] o ser se diz de muitos modos [...]" (1998, p. 151 - tradução nossa). Tais modos são os seguintes: segundo ato e potência, segundo o acidente, segundo o verdadeiro e o falso e segundo cada uma das categorias, identificadas pelo filósofo como "figuras da predicação" (p. 308).

As figuras da predicação são as formas como se pode falar do ser e são apresentadas como " [...] o quê, de que qualidade, de que tamanho, onde, quando e se alguma outra significa do mesmo modo." (p. 308-9), ou seja, substância, qualidade, quantidade e relação. Também são utilizados os termos atributos e ação, com a identificação das demais formas, como a inclusão da mudança e das condições espaço-temporais.

Em síntese, as figuras da predicação significam as coisas:

[...] em quantos são os modos em que se diz, tantos são os significados do ser [...] quanto aos predicados, uns significam essências, outros qualidade, outros quantidade, outros relação, outros agir ou padecer, outros lugar e outros tempo, o ser significa o mesmo que cada um destes (ARISTÓTELES, 1998, p. 245 tradução nossa).

A partir disto, no que concerne às formas categoriais, o ser se diz de oito modos interrelacionados:

a) substância: que é o modo principal do ser, e que serve de fundamento a todos os outros modos, a saber:

b) qualidade;

c) quantidade;

d) relação;

e) agir;

f) sofrer ;

g) lugar;

h) tempo.

A figura 1 apresenta um esquema da classificação da realidade inspirado nos ensinamentos de Aristóteles (1998) e dele extraído.

\section{FIGURA 1}

\section{As categorias aristotélicas}

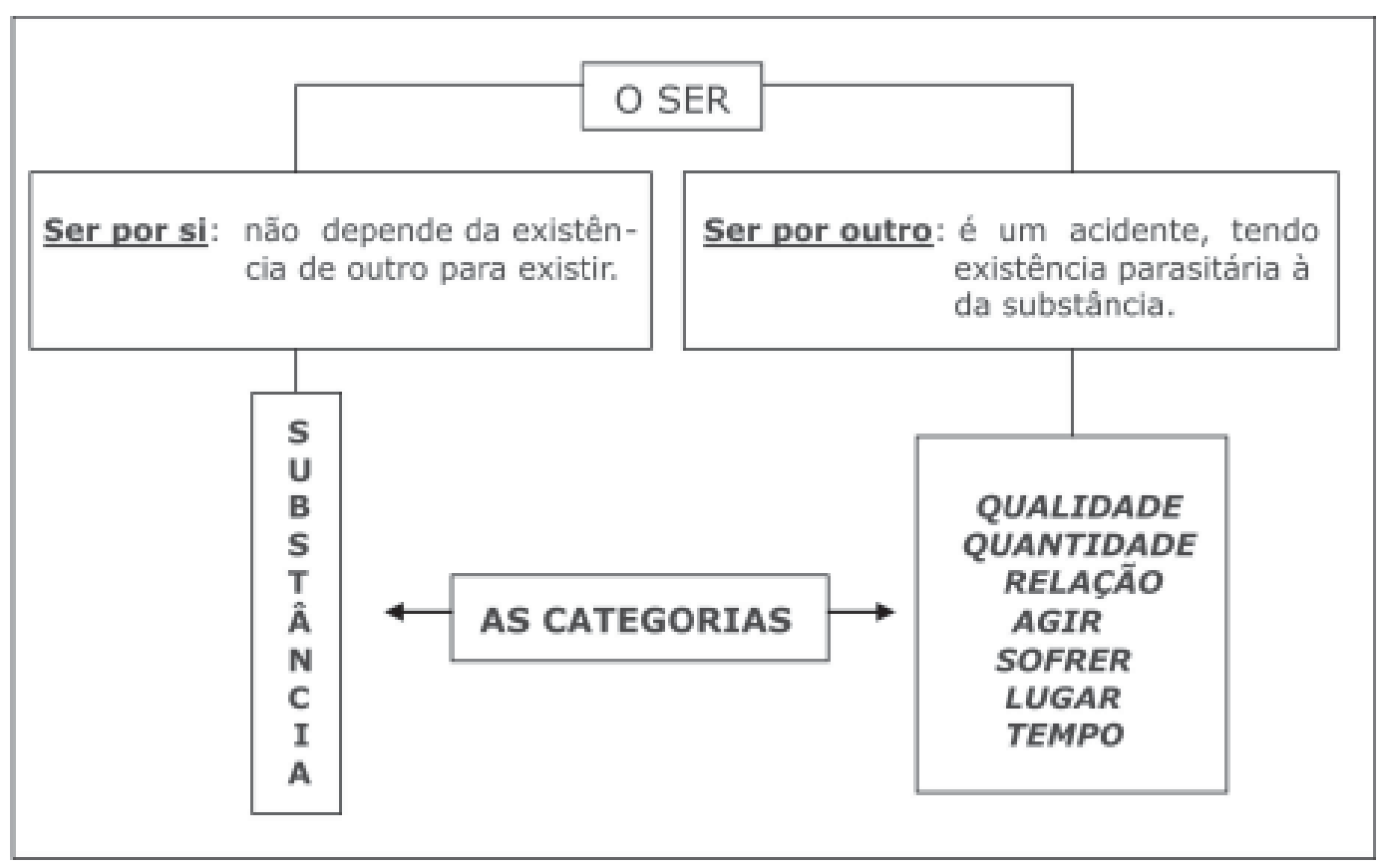


A categoria da substância ${ }^{3}$ é a principal dentre as categorias e à qual todas as outras fazem referência. Para o filósofo, o termo 'substância' é atribuído

[...] a uma categoria de coisas, distinguida no seio do próprio real. Ele separa nos seres aquilo que é substância daquilo que não é por meio de uma definição que fixa os caracteres próprios dela (MANSION, 2005, p. 75).

A substância é o ser no sentido primeiro e fundamental e, por esta razão, figura no topo da lista das categorias. As oito categorias são recortes que o pensamento humano faz da realidade, sendo elas um produto lógico, isto é, um produto do pensamento e de sua expressão, a linguagem, fidelíssimo às junturas existentes na própria realidade. Isto é possível, pois, aos olhos de Aristóteles, a linguagem está perfeitamente colada ao mundo, sendo, assim, capaz de revelá-lo.

O uso da linguagem, seja através da escrita ou da fala, é efetivado basicamente por proposições. Tais proposições são constituídas minimamente pelo que Aristóteles chama de um nome e um verbo, ou no linguajar mais recente, de um sujeito e um predicado. Quando se diz que "Sócrates é branco", 'Sócrates' figura como sujeito e 'é branco' como predicado. Falar de Sócrates desse modo é identificá-lo como substância e ‘branco’ como uma

\footnotetext{
3 Aristóteles, em sua Metafísica, almeja fazer uma ontologia geral cujo fio condutor é a questão do que é 'ser primeiro', ou seja, o que é ser em sentido mais fundamental. Esta questão encontra como resposta (parcial) as substâncias naturais do mundo. Assim, os artefatos, ou seja, o que é produzido pela espécie humana, não são 'substância' em sentido estrito e próprio, mas apenas em sentido derivado. Tal sentido se explica na medida em que podemos observar uma semelhança entre a estrutura das substâncias e a dos artefatos, pois ambas são compostas de matéria e forma. Tomando como exemplo um livro, observa-se que ele é composto de uma matéria e de uma forma, que lhe permite ser identificado como o que é, tal como ocorre com as substâncias naturais. Aplicando as categorias ao artefato livro, temos o seguinte: 'o livro é verde' ("substância" + qualidade); 'o livro pesa quinhentos gramas e mede vinte e cinco centímetros de altura' ("substância” + quantidade); 'o livro verde tem o dobro do peso do livro azul' ("substâncias" + relação); 'o livro foi restaurado' ("substância" + sofrer); 'o livro está na Biblioteca de Alexandria' ("substância" + lugar); 'o livro foi publicado em 2008' ("substância" + tempo). A categoria da ação não encontra paralelo entre os artefatos, uma vez que eles não possuem potência para agir, mas apenas para sofrer.
}

qualidade pertencente a ela. Por sua vez, a 'brancura' desta substância não pode subsistir por si só, sendo inteiramente dependente da substância.

O mesmo que ocorre com a brancura se dá com as demais categorias que designam seres cuja existência é sempre parasitária à existência da substância: por exemplo, o peso e a estatura (categoria da quantidade) de Sócrates dependem de Sócrates para existirem. O tipo de existência das coisas pertencentes à categoria da relação, tais como "ser mais alto que", "ser maior que", "ser o dobro de", depende da existência de pelo menos duas coisas que existem por si, ou seja, de duas substâncias. Assim, quando uma proposição afirma que Sócrates é mais alto que Xantipa, a relação 'mais alto que' depende tanto da existência de Sócrates quanto da de Xantipa, pois o termo relacional, a altura, como já fora dito, não pode existir independentemente do ser de Sócrates e do ser de Xantipa.

As coisas que recaem sob a categoria da ação dependem igualmente, para existirem, de algo que existe como substância. A ação de podar ou de queimar uma árvore, por exemplo, depende de um sujeito substancial: um homem que opere a poda ou ateie o fogo. Se considerarmos a mesma situação do ponto de vista daquilo que sofre a ação de ser podado ou queimado, a mesma dependência, em relação à categoria da substância, torna-se clara para a categoria do 'sofrer', pois o fato de uma árvore ser podada ou queimada, por exemplo, depende da existência da árvore, a qual é uma substância.

Idêntica relação parasitária se dá entre as categorias do lugar e do tempo em relação à categoria da substância. Os predicados que designam ocupação de lugar no espaço dependem, evidentemente, de um sujeito substancial ou, pelo menos, de um sujeito que faça as vezes de uma substância, mesmo que, a rigor, não o seja, como é o caso de todos os artefatos, por exemplo. Esse sujeito substancial está sempre em algum lugar, tal como quando se diz que Aristóteles está no Liceu e que Sócrates está na praça. 
Do mesmo modo, todos os predicados pertencentes à categoria do tempo remetem, em última instância, a algo que pertence à categoria da substância. Tendo tudo isto em vista, para poder ser um espelho da realidade, a linguagem precisa estabelecer um comportamento distinto entre a categoria da substância e as demais, visto que a primeira é ser em sentido primordial, 'o ser por si', pois é dela que depende a existência de todos os outros seres categoriais, 'os seres não por si'. É por esta razão que o representado por ela funcionará como sujeito das proposições e os acidentes como predicados. Deste modo, pode-se observar que as categorias revelam a condição ontológica da realidade sobre a qual se pensa e se fala por meio delas.

As categorias aristotélicas se mostram, portanto, como unidades cognitivas que guiam a apreensão da multiplicidade, pois é sob tais unidades que distinguimos e classificamos os vários modos em que o ser se apresenta. Por exemplo, os conceitos que nós temos de homem, de cavalo, de árvore podem ser subsumidos sob um conceito mais geral: a categoria da substância e assim sucessivamente com as demais categorias. Nota-se, então, que para Aristóteles as categorias operam a separação e a classificação do variegado de seres que preenche o mundo.

\section{Reformulação kantiana}

Tal como Aristóteles, Immanuel Kant foi de importância fundamental para a sistematização do conhecimento: o filósofo alemão se coloca ao lado do estagirita no sentido de que elaborou sua análise tanto partindo da multiplicidade que o mundo apresenta, quanto buscando princípios de unidade capazes de propiciar o conhecer. Seu labor intelectual contemplou pesquisas e estudos sobre o saber humano, redefinindo conceitos, reformulando teorias e estabelecendo novas formas de ver o mundo. Desse modo, tentou sintetizar os vários padrões de conhecimento existentes na época, que identificou como racionalismo, empirismo, idealismo e realismo. Além disto, buscou oferecer respostas satisfatórias à posição dos céticos. Nas palavras do filósofo, somente uma crítica bem fundamentada poderia

[...] cortar pela raiz o materialismo, o fatalismo, o ateísmo, a incredulidade dos espíritos fortes, o fanatismo e a superstição, que se podem tornar nocivos a todos (KANT, 1997, p. 30).

A crítica efetuada e a síntese proposta operam uma reflexão sobre a razão, concebida como ordenadora de todo conhecimento, questionando o valor dela, investigando criticamente as condições pelas quais se pode conhecer, bem como inquirir sobre os limites para este conhecimento, guiado por princípios organizadores com o uso lógico do entendimento pelas categorias. Desta maneira, a posição kantiana também se opõe a todo dogmatismo, compreendido como o procedimento intelectual "[...] sem uma crítica prévia de sua capacidade.” (KANT, 1997, p. 30).

À medida que criticou os pressupostos teóricos de cada um dos modelos de pensamento apresentados, Kant elaborou sua própria concepção, denominada 'idealismo transcendental', propiciando verdadeira revolução na filosofia e nas ciências. Por 'idealismo', entende-se o estudo das representações de existências enquanto adequadas a ideias. Por 'transcendental', o filósofo concebe todo conhecimento em relação não com tais existências, mas na maneira como o ser humano pode conhecêlas. Logo, o foco da investigação recai sobre a estrutura cognitiva humana e suas formas de representar as coisas do mundo.

O idealismo transcendental concebe que o intelecto está ativamente envolvido com as coisas que experimenta, isto é, as coisas capazes de serem conhecidas passam por um processo de organização e de classificação propiciado pelo uso das categorias mentais, as quais se caracterizam como componentes inerentes ao aparato intelectual humano, não se constituindo a partir do contato com os objetos, mas, pelo contrário, sendo elas próprias as condições pelas quais esses objetos podem ser conhecidos. 
Disto se segue uma diferença fundamental da concepção aristotélica: o pensador alemão reconhece a importância e a grandiosidade do trabalho desenvolvido pelo estagirita, mas a análise de Aristóteles o coloca ora na classe dos realistas, ora na classe dos empiristas, indicando que qualquer uma das duas posições contém certa dose de ingenuidade. A explicação kantiana é que os empiristas reduzem todo conhecimento à experiência sensível. Por seu turno, os realistas acreditam num acesso imediato e direto aos objetos do conhecimento. Kant critica ambas as concepções, estabelecendo critérios para o conhecimento e concebendo seus objetos como coisas em si e fenômenos, como será explicitado na sequência.

Ao estabelecer os critérios para o conhecimento, Kant propõe uma reformulação das categorias aristotélicas, buscando torná-las dependentes das formas do juízo. A nova concepção kantiana toma tais formas como as maneiras fundamentais de pensar os objetos de acordo com as estruturas segundo as quais a mente humana pode concebêlos, entendê-los e expressá-los através da linguagem. A análise das categorias kantianas tem como foco principal a Crítica da Razão Pura, obra em que Kant apresenta sua "Tábua das Categorias” (1997, p. 110-1), mas busca subsídios também nos Prolegômenos a Toda Metafísica Futura, em que as categorias também são abordadas.

A seção 'Analítica Transcendental' da Crítica expõe uma argumentação sobre as condições do conhecer, pretendendo limitar o conhecimento legítimo às condições da experiência humana. Nela, Kant apresenta o que concebe como categorias a priori ${ }^{4}$ ou conceitos puros, que são exatamente as categorias de que este artigo trata.

A crítica kantiana centra sua reflexão filosófica no sujeito e nas suas capacidades cognitivas. Assim, o problema que se coloca diz respeito a como é possível conhecer. Para o pensador, não é porque

\footnotetext{
${ }^{4}$ A priori é uma expressão oriunda do latim que significa antes, anterior. Na terminologia kantiana, ela assume o justo significado de independentemente de toda experiência.
}

o sujeito percebe as coisas exteriores a si mesmo e exteriores umas às outras que forma a estrutura de espaço. É porque possui o espaço com uma estrutura inerente à sua sensibilidade que o sujeito pode perceber objetos relacionados espacialmente, ou seja, o sujeito possui em si tal estrutura. Do mesmo modo, o tempo também é inerente ao sujeito cognoscente. É a estrutura temporal que permite representar as coisas simultânea e/ou sucessivamente.

O espaço e o tempo ${ }^{5}$ não são considerados categorias, mas formas elementares puras da sensibilidade. Sendo identificadas como formas da intuição, elas representam a maneira como uma consciência se relaciona e experimenta objetos e eventos tanto espacialmente extensivos quanto temporalmente sucessivos. Abbagnano (1994, p. 65) esclarece que essas formas não são "[...] qualidades das coisas, mas condições da nossa intuição delas". Logo, o sujeito cognoscente não pode perceber nada que não esteja submetido às condições espaço-temporais.

Estas formas da intuição e as categorias do entendimento acompanham o ser humano nos processos de conhecer e de reconhecer o mundo e os fenômenos que o constituem. De uma perspectiva ideal, a ciência baseada nestas categorias é igualmente universal, constituindo um sistema de conhecimento que se aplica a qualquer fenômeno porque é acessível a qualquer consciência que observe tais fenômenos.

Pode-se perceber outra diferença marcante em relação à concepção aristotélica, visto que o estagirita considera o espaço e o tempo como categorias fundamentais e Kant (1997, p. 25) as

\footnotetext{
${ }^{5}$ Os conceitos de espaço e de tempo são essenciais ao idealismo transcendental e a elaboração kantiana sobre eles é extremamente rica e complexa. Entretanto, a abordagem aprofundada deste tema acabaria por desvirtuar o foco deste trabalho. Conforme Torretti, "a Crítica da Razão Pura caracteriza o espaço como forma do sentido externo; o tempo, analogamente, como forma do sentido interno." (1967, p. 209). Este comentador oferece texto minucioso e apurado sobre a idealidade do espaço e do tempo, no qual a considera como "fundamento da filosofia crítica de Kant." (p. 489). Para aprofundar o assunto, é sugerida a leitura da obra citada.
} 
considera como estruturas inerentes ao aparato cognitivo humano, sendo:

[...] apenas formas da intuição sensível, isto é, somente condições da existência das coisas como fenômenos e que, além disso, não possuímos conceitos do entendimento e, portanto, tão poucos elementos para o conhecimento das coisas, senão quando nos pode ser dada a intuição correspondente a esses conceitos.

Os conceitos do entendimento são exatamente as categorias, mas assumem um sentido diferente da elaboração aristotélica. A reformulação das categorias efetuada pelo pensador alemão pretende estabelecer fundamentos que permitam investigar e identificar as faculdades e capacidades humanas, explicitando a que objetos se aplicam já que se tratam de faculdades distintas cujo foco se direciona a objetos também distintos. Tais faculdades são apresentadas como sensibilidade, entendimento e razão, sendo critérios mediante os quais se efetua a passagem do entender ao conhecer que será, em linhas muito gerais, exposta na sequência.

Para Kant, é essencial distinguir os objetos das respectivas faculdades, bem como os modos distintos de considerar cada objeto para esclarecer as condições do conhecimento humano. O entendimento, "[...] faculdade da conexão das intuições dadas numa experiência [...]" (KANT, 2003, p. 94) em sua subordinação ao âmbito da sensibilidade, requer que um objeto sensível, que se apresenta a um sujeito cognoscente, seja intuído sensivelmente, isto é, esteja submetido às formas espaço-temporais da sensibilidade.

Ao que aparece a um sujeito cognoscente, respeitando as formas da intuição sensível, Kant denomina fenômeno, em contraposição à coisa em si, que está além da sensibilidade e, em função desta razão, além da possibilidade de ser intuída. O fenômeno é o limite da experiência. Este limite é dado no sentido de que tudo que podemos conhecer está submetido às condições espaçotemporais. Porém, isto não significa negar existência às coisas externas ao sujeito que podem estar inacessíveis à sua estrutura cognitiva. Para Kant, tais coisas têm uma realidade que ultrapassa tal estrutura cognitiva.

Por 'cognição' se adota, neste trabalho, a definição elaborada por Moreira e Masini (1982, p. 3): ${ }^{6}$

É o processo através do qual o mundo de significados tem origem. À medida que o ser se situa no mundo, estabelece relações de significação, isto é, atribui significados à realidade em que se encontra. Esses significados não são entidades estáticas, mas pontos de partida para a atribuição de outros significados. Tem origem, então, a estrutura cognitiva (os primeiros significados), constituindo-se nos pontos básicos de ancoragem dos quais derivam outros significados.

Por sua vez, o que foi denominado 'pontos básicos de ancoragem' deve ser entendido como unidades de sentido formadas a partir da incorporação, à estrutura cognitiva, de elementos como informações ou ideias, que sejam relevantes para a aquisição de novos conhecimentos e para a organização destes, de forma a, progressivamente, generalizarem-se, formando conceitos. Este processo de conceitualização, que significa subsumir impressões particulares a representações e conceitos gerais

[...] visa essencialmente a romper o isolamento do dado 'aqui e agora', para relacioná-lo com outra coisa e reuni-lo aos demais numa ordem inclusiva, na unidade de um 'sistema' (CASSIRER, 1992, p. 43).

Esta conceitualização é elaborada pelos sujeitos do conhecimento. Da perspectiva cognitiva kantiana, o sujeito é

[...] veículo de todos os conceitos em geral [...], e de uma perspectiva transcendental, $[. .$.$] serve$

${ }^{6}$ MOreira, M. A.; MASIni, E. F. S. Aprendizagem Significativa: a teoria de David Ausbel. São Paulo: Moraes, 1982, p. 3 apudBOCK, Ana Mercês Bahia; FURTADO, Odair; TEIXEIRA, Maria de Lourdes Trassi. Psicologias: uma introdução ao estudo de psicologia. 13. ed. São Paulo: Saraiva, 1999, p. 117. 
para apresentar todo pensamento como pertencente à consciência (KANT, 1997, p. 327).

Esse sujeito é a própria possibilidade do conhecimento, mas não apenas porque pensa, pois, desta maneira, o máximo que poderia exprimir é que pensa que pensa. O sujeito conhece porque é capaz de unificar os dados do conhecimento numa consciência, isto é, o sujeito cognoscente pode realizar um uso teórico das categorias para subordinar o múltiplo sensível, formular suas ideias e submetê-las à unidade da consciência.

O pensamento pertence à consciência e é veículo da experiência, isto é, a consciência acompanha toda experiência. Entretanto, a causa desta consciência não pode ser dada pela experiência. O sujeito kantiano é "[...] a unidade da consciência, que serve de fundamento às categorias." (KANT, 1997, p. 359).

Para Kant, as categorias são estruturas lógicas comuns a todos os seres humanos. São pura forma. No caso, a forma lógica por meio da qual se formam os juízos, expressando a maneira como se fala das coisas do mundo. Assim, as categorias se caracterizam como instrumentos para a produção do saber, sendo conceitos básicos e elementares e, portanto, simples e não-analisáveis.

Elas são estruturas cognitivas vazias e, desta perspectiva, possibilitam representar o objeto do conhecimento segundo o que constitui o seu conceito, isto é, as notas características que indicam o que ele é. Entretanto, o conceito do objeto já é a posteriori, enquanto as categorias são $a$ priori por serem a própria condição para uma conceitualização dos objetos do conhecimento.

Como expõe Abbagnano (1974, p. 148), as categorias

são os modos por meio dos quais se manifesta a atividade do entendimento, que consiste essencialmente em ordenar diversas representações sob uma representação comum, isto é, julgar..
Como já foi adiantado, elas são as formas do juízo, pois a exposição kantiana deriva todas as categorias de cada uma das formas apresentadas na "Tábua dos Juízos" (KANT, 1997, p. 104). É a partir dela que emergem as categorias. $\mathrm{O}$ que relaciona as categorias com os juízos é a síntese, ou seja, o que dá unidade a uma multiplicidade, pois é a síntese que permite reunir diversas representações sob um conceito mais geral que expresse suas características essenciais.

As categorias kantianas possuem duas características básicas. Em primeiro lugar, elas se aplicam unicamente na relação sujeito-objeto, da qual o resultado é o conhecimento dos fenômenos, isto é, do que está de acordo com a capacidade do entendimento humano. Em segundo lugar, elas são as determinações objetivas desta relação e, desse modo, aplicam-se a qualquer ser humano.

A Tábua das Categorias se constitui de 12 conceitos distribuídos em quatro grandes grupos: quantidade, qualidade, relação e modalidade. Os dois primeiros dizem respeito às categorias matemáticas, e os outros dois são caracterizados como categorias dinâmicas. A caracterização está relacionada aos juízos, ou seja, à maneira como se fala dos objetos, sendo que o objeto das categorias matemáticas são os objetos da intuição. Em contrapartida, as categorias dinâmicas dizem respeito à existência dos objetos em suas relações entre si e com o entendimento. Cada grupo se subdivide em três categorias, sendo que as duas primeiras formam uma dicotomia, ou seja, uma oposição, enquanto a terceira resulta da síntese das duas, isto é, da combinação entre elas.

A apresentação kantiana é a seguinte:

a) quantidade: unidade, pluralidade e totalidade;

b) qualidade: realidade, negação e limitação;

c) relação: inerência-subsistência, causalidadedependência e comunidade;

d) modalidade: possibilidade-impossibilidade, existência-não-existência e necessidadecontingência. 
O fundamento de todo conhecimento remete às categorias de quantidade, pois elas são concebidas como exigências lógicas e critérios para o saber. A unidade representa a medida e a pluralidade representa a multiplicidade. A totalidade, por sua vez, representa a pluralidade considerada como unidade, ou seja, a síntese das duas outras formas categoriais.

A realidade é a primeira das categorias de qualidade e corresponde à função afirmativa do juízo. Ela indica aquilo cujo conceito em si próprio é um ser, sendo apenas por intermédio dela que os objetos podem ser identificados como algo. Tem por oposição a negação, que indica um não-ser. A limitação, terceira categoria, mapeia até que ponto algo pode ser o que é e, assim, revela a síntese da realidade com a negação.

Das categorias de relação, a inerência/subsistência é a que Aristóteles compreendia como substância (a categoria primordial) e acidente (as demais categorias aristotélicas). Por sua vez, causalidade/ dependência corresponde à causa e efeito com os predicáveis da força, ação e sofrer. Finalmente, comunidade diz respeito à ação recíproca entre agente e paciente, com os predicáveis de presença e de resistência. Esta forma categorial expressa a causalidade de uma substância e os efeitos recíprocos de suas determinações com outras substâncias.

As categorias modais prescrevem como os objetos podem ser determinados em termos de possibilidade, existência e necessidade, ou seja, não determinam o objeto, pois isto só pode ser feito pelas outras categorias: quantidade, qualidade e relação, mas, em contrapartida, elas determinam a forma como se concebe este objeto. A existência, a possibilidade e a necessidade indicam o modo como se fala dos objetos, sendo que nenhuma tem prioridade sobre as outras. A terceira categoria, a necessidade, é a síntese da realidade dada pela própria possibilidade: em outras palavras, ela se afigura em síntese das duas outras formas categoriais.

A seguir, uma representação gráfica da apresentação kantiana. Aqui é importante esclarecer que a numeração e a posição dos grupos e das categorias são fiéis à tábua das categorias. Apesar da estrutura da apresentação, não existe relação hierárquica entre os diferentes grupos categorias, nem entre as categorias. Elas são concebidas como igualmente fundamentais. A figura 2, com pequenas alterações formais, encontra-se na Crítica da Razão Pura (KANT, 1997, p. 110-1):

\section{FIGURA 2}

\section{As categorias kantianas}

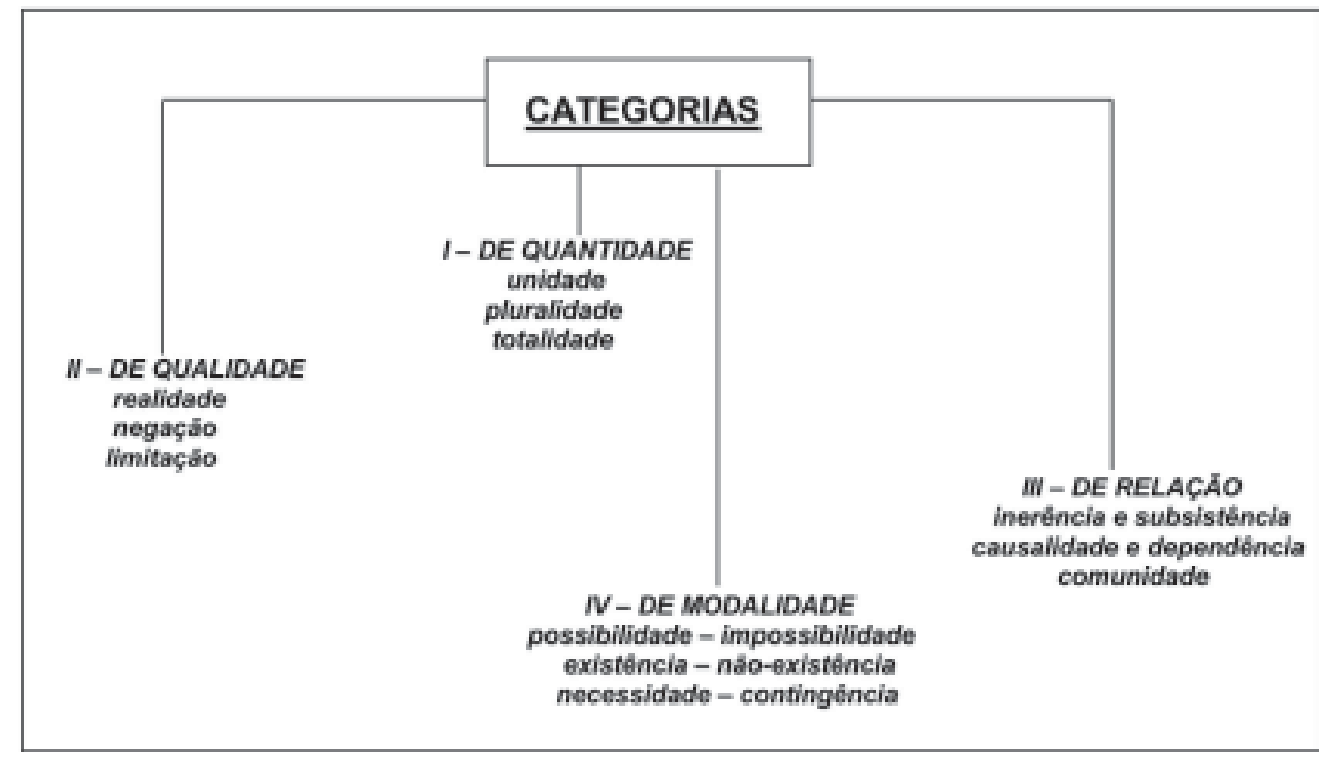


Ele indica que as categorias necessitam de um esquema, definido como "[...] a condição geral pela qual unicamente a categoria pode ser aplicada a qualquer objeto" (1997, p. 182-3), e revela como elas são utilizadas. Esta condição é satisfeita quando a imaginação fornece a um conceito a sua imagem. Nesse procedimento mental, a representação da categoria de quantidade é o número, da qualidade é a 'coisidade' (a essência que faz a coisa ser o que é, ou seja, suas características fundamentais), que indica realidade, negação e limitação. Já a representação da relação é a permanência, sucessão e simultaneidade. A da modalidade, por seu turno, é a existência no tempo, sendo que pode ser em um tempo qualquer, exprimindo possibilidade; em tempo determinado, expressando realidade; ou em todos os tempos, representando a necessidade.

Com isto, temos a representação espaço-temporal que reaparece nas categorias kantianas como "esquema", ou seja, como condicionada pelas categorias, mas não como constituinte delas. Esta é uma entre tantas distinções que afasta a reformulação kantiana das categorias aristotélicas. Ranganathan, ao conceber suas categorias, recoloca o tempo e o espaço como categorias fundamentais, como veremos na sequência.

\section{Perspectiva de Ranganathan}

Shiyali Ramamrita Ranganathan é considerado o grande teórico da classificação bibliográfica. Dos seus estudos e reflexões surgiu um trabalho inovador e solidamente fundamentado. É bem verdade que diversos estudiosos desenvolveram trabalhos relevantes para a teoria da classificação, mas Xiao (1994) considera que os classificacionistas anteriores construíram esquemas tendo por base sistemas de áreas especializadas. Assim, não aprofundaram a própria teoria e deixaram lacunas na fundamentação destes esquemas.
Campos (2001, p. 32) ressalta e complementa esse ponto ao afirmar que os sistemas anteriores ao de Ranganathan só permitiam representar o conhecimento já estabelecido, pois neles “[...] não ocorre a ligação entre o conhecimento e as classificações, mas entre os assuntos dos documentos e as classificações". É exatamente como alternativa a esta concepção rígida e carente de fundamentos científicos que Ranganathan desenvolve um trabalho que busca compatibilizar uma classificação flexível, expansiva e prática com bases reconhecidamente científicas, sem tornar o sistema inconsistente ou inviável. A compatibilização destes elementos permitirá uma única classificação capaz de atender a todos os propósitos. Nela, os esquemas e as características utilizadas como base para a elaboração de facetas são sempre manifestações de cinco categorias básicas.

Por 'categoria', a perspectiva ranganathiana compreende um conceito de alta generalidade e de larga aplicação que serve de estrutura a um esquema de classificação, pois sob este esquema se pode reunir outros conceitos. Devido a tais características, categorias fundamentais podem ser aplicáveis a grande parte do conhecimento existente.

'Faceta', por sua vez, é a manifestação das categorias em classes distintas. As facetas pertencem aos assuntos dos documentos, sendo o resultado da aplicação de características que formam um conjunto cujo nome é o termo mais geral. Sob uma faceta recaem componentes subordinados, mas com características particulares.

As bases formuladas para o estabelecimento da classificação objetivada por Ranganathan incluem princípios que envolvem três planos de trabalho: $\mathrm{o}$ das ideias, o verbal e o notacional. A este trabalho interessa mais o primeiro nível, no qual se encontra a estratégia de classificação cristalizada na elaboração das categorias fundamentais, conhecidas pelo acrônimo PMEST Personalidade, Matéria, Energia, Espaço e Tempo. 
Cada letra se refere à inicial de uma das cinco categorias, conforme a denominação da língua inglesa, idioma em que Ranganathan escreveu suas obras.

A aplicação das categorias está direcionada para uma análise estrutural da organização documentária como resposta às questões sobre como os assuntos são formados. Inicialmente foram definidos conjuntos de conceitos que permitissem identificar os assuntos e classificá-los com coerência e consistência. Os conjuntos foram denominados 'universos originais', cada qual contendo uma série de características reveladoras de uma faceta do universo do conhecimento que, por sua vez, serão sempre manifestações das categorias fundamentais PMEST.

O caminho para se chegar aos princípios últimos de uma classificação que abarcasse o desenvolvimento do próprio conhecimento e sua projeção em novas áreas aponta para cinco direções apresentadas em Prolegomena (1967, p. 351-358), que são, respectivamente:

a) dissecação: resulta em classes coordenadas ou em ordem de classes;

b) laminação: resulta em classes compostas;

c) desnudação: resulta em classes subordinadas ou em cadeias de classes;

d) montagem flexível;

e) superposição: que resulta em combinação de classes através de reunião e agregação. ${ }^{7}$

Definindo os caminhos para a elaboração de novas classes e

[...] estudando atentamente o tipo de faceta a ser encontrado em diferentes classes básicas, ele

${ }^{7}$ Vickery (1980) considera que a superposição poderia ser subsumida ao modo de montagem flexível, pois é um instrumento para esta elaboração, juntamente com a reunião e a agregação. Assim, seriam quatro as direções para a formação dos assuntos. pode determinar que, apesar de suas aparentes diferenças superficiais, essas facetas poderiam ser acomodadas em cinco grandes grupos (FOSKETT, 1973, p. 265).

O estudo e a avaliação dos níveis do universo de assuntos conduzem à formulação de alguns princípios gerais. Segundo Ranganathan (1967, p. 396 - tradução nossa), deve-se "[...] parar brevemente no nível final. Mas em que nível devemos parar?" O próprio pensador responde: "[...] até que encontremos somente cinco ideias genéricas ou seminais finais.". Sobre essas ideias não se pode julgar a verdade ou a falsidade, pois, se elas provarem sua utilidade, devem apenas ser postuladas e servir de instrumento de trabalho. Logo, elas são apenas supostas, não podendo ser objetos de definições.

Ora, a análise precisa parar em um ponto firme para que o trabalho de classificação comece, visto que uma regressão ao infinito impossibilita a ação. Tal ponto se revela satisfatório com o estabelecimento de cinco ideias que permitem o início do trabalho de classificação. O próprio Ranganathan reconhece que, se tais ideias não se revelarem mais úteis, podem e devem ser modificadas. Entretanto, baseando a classificação prática nelas, como o método postulacional

os assuntos caem em uma sequência útil [...] e o esquema resultante para a classificação é uma Classificação Livremente Facetada em cada sentido do termo (1967, p. 397 - tradução nossa).

Resta ainda a questão de saber por que o número é cinco. Ranganathan (1967) afirma que qualquer pessoa tem total liberdade para formular o número de categorias que quiser, desde que elas sejam empiricamente testadas. Para tanto, sugere que se classifiquem alguns milhares de artigos: se os resultados forem satisfatórios, o novo postulado pode ser aceito. Ou seja, ressalta o critério da utilidade, pois é este o fundamento das categorias ranganathianas: que sejam úteis ao processo 
classificatório, até porque é preciso começar de algum ponto e esse ponto é indicado como a necessidade de submissão do potencialmente infinito universo de assuntos a termos mais gerais que lhes dêem sentido e enquadramento dentro da perspectiva de classificação do conhecimento registrado.

Com isto, Ranganathan (1967, p. 399 - tradução nossa) apresenta o seu postulado das categorias fundamentais: "Há cinco e somente cinco categorias fundamentais: Tempo, Espaço, Energia, Matéria e Personalidade". Ressalta ainda que seu contexto se restringe à classificação bibliográfica, na qual o significado dessas categorias indica somente as facetas de um assunto, estando, portanto, longe da aplicação em disciplinas como a metafísica e a física, objetos das categorias formuladas por Aristóteles e Kant, como vimos.

As categorias são indivisíveis e, portanto, fundamentais. Assim, "não podemos saber o que as 'Categorias Fundamentais' são." (RANGANATHAN, 1967, p. 398 - tradução nossa). Elas são definidas somente pela enumeração. O essencial é que elas podem e devem originar novas categorias. Entretanto, as últimas são sempre a posteriori, isto é, resultado da aplicação dos princípios primeiros às entidades. Portanto, elas precisam da observação e da experiência. Por meio disto, todos os assuntos poderiam ser subsumidos às categorias fundamentais 'PMEST', as quais são apresentadas na sequência com breve tentativa de explicação, apesar da dificuldade de definições indicada pelo seu autor:

a) P (personalidade): é constituída de entidades, seus tipos ou espécies e respectivas partes ou órgãos. Por este motivo, pode-se identificar os conceitos de entidade, coisa, todo, produto final, tipos ou espécies, partes ou órgãos com essa categoria fundamental. Ela é considerada por Ranganathan como indefinível; b) M (matéria): compreende o material de que são feitas as coisas e as suas respectivas propriedades. Engloba os elementos constitutivos, estrutura, forma, matéria e propriedades. Inclui tanto propriedades materiais quanto abstratas. Por exemplo: madeira que constitui uma mesa, assim como sua forma e cor;

c) E (energia): indica tanto qualquer tipo de ação como também reações, processos, operações e problemas;

d) S (espaço): traduz o aspecto espacial geográfico dos assuntos analisados que recaem sob essa categoria. Inclui divisões geográficas de continente, de país etc;

e) $\mathrm{T}$ (tempo): refere-se ao aspecto cronológico dos assuntos e à limitação de períodos, séculos, décadas etc.

A dificuldade em determinar um número adequado de categorias que abrangessem a totalidade dos assuntos possíveis para uma classificação bibliográfica

[...] levou Ranganathan ao seu conceito de categorias 'fundamentais' das quais todas as categorias particulares são manifestações. As cinco categorias fundamentais por ele citadas acham-se numa ordem que ele declarou ser de 'concretividade decrescente' [...] (VICKERY, 1980, p. 53).

Para analisar o que seria tal ordem, serão oferecidos exemplos que permitam compreender que tipo de objeto se subsume a cada uma das categorias fundamentais. O objetivo primordial das categorias de Ranganathan é exatamente permitir a subsunção de particulares a uma classe mais geral para conhecê-los e organizá-los. Imagine-se, portanto, um documento impresso na forma de livro e que trate da arte de catalogar, publicado em Porto Alegre, em 2008. A Personalidade incluiria a 'Biblioteconomia'; a Matéria, 'Livro'; a Energia, 'Catalogação'; o Espaço seria Porto Alegre e, para finalizar, o Tempo seria o ano de 2008. 
Tendo em vista a noção de 'concretividade decrescente', parece problemático admitir que Biblioteconomia, que é uma abstração efetuada a partir da matéria - no caso, livro - seja mais concreta que a própria matéria que deu origem a esse conceito mais geral. Em verdade, Ranganathan não oferece uma definição exata da categoria 'Personalidade', na qual justamente recairia o termo escolhido como exemplo.

Foskett reconhece que

[...] é difícil definir Personalidade, mas é fácil compreender o que ela é; ela corresponde àquilo que chamamos de faceta primária e normalmente inclui coisas (1973, P. 266).

Vickery (1980), por sua vez, salienta que, além da falta de uma definição mais palpável, a teoria se ressente da carência de uma análise mais apurada de suas relações com as demais categorias. Em termos gerais, no entanto, considera-as instrumentos úteis e satisfatórios para uma análise adequada dos assuntos de um documento, pois, como princípios elementares, servem de orientação para que a análise possa ser iniciada. Portanto, elas são a base para que se possa efetuar uma análise de qualquer material a ser classificado no âmbito da documentação, independentemente da sua forma e do seu suporte.

Analisando os exemplos oferecidos anteriormente, pode-se facilmente constatar que as categorias elaboradas por Ranganathan buscam responder às questões fundamentais do 'por quê', 'o quê', 'como', 'onde' e 'quando'. Dessa perspectiva, a concretividade proposta pelo bibliotecário indiano ganha sentido. A causa - isto é, o 'por quê' - é necessariamente mais concreta que o seu efeito, ou seja, o 'o quê'. Assim, o ramo do conhecimento de que surge uma nova entidade é mais concreto do que a própria entidade, por ser a causa dela.

A publicação de um livro sobre catalogação é um efeito da existência de um ramo do conhecimento que estuda e organiza os materiais bibliográficos. A partir daí, novas questões se seguem e podem ser respondidas pelas categorias fundamentais que, como o próprio nome indica, são fundadoras e possibilitadoras do uso de novas categorias delas derivadas.

$\mathrm{Na}$ figura 3, a representação gráfica baseada na apresentação de Ranganathan (1967, p. 399-401) e de acordo com a ordem de concretividade.

FIGURA 3

As categorias ranganathianas

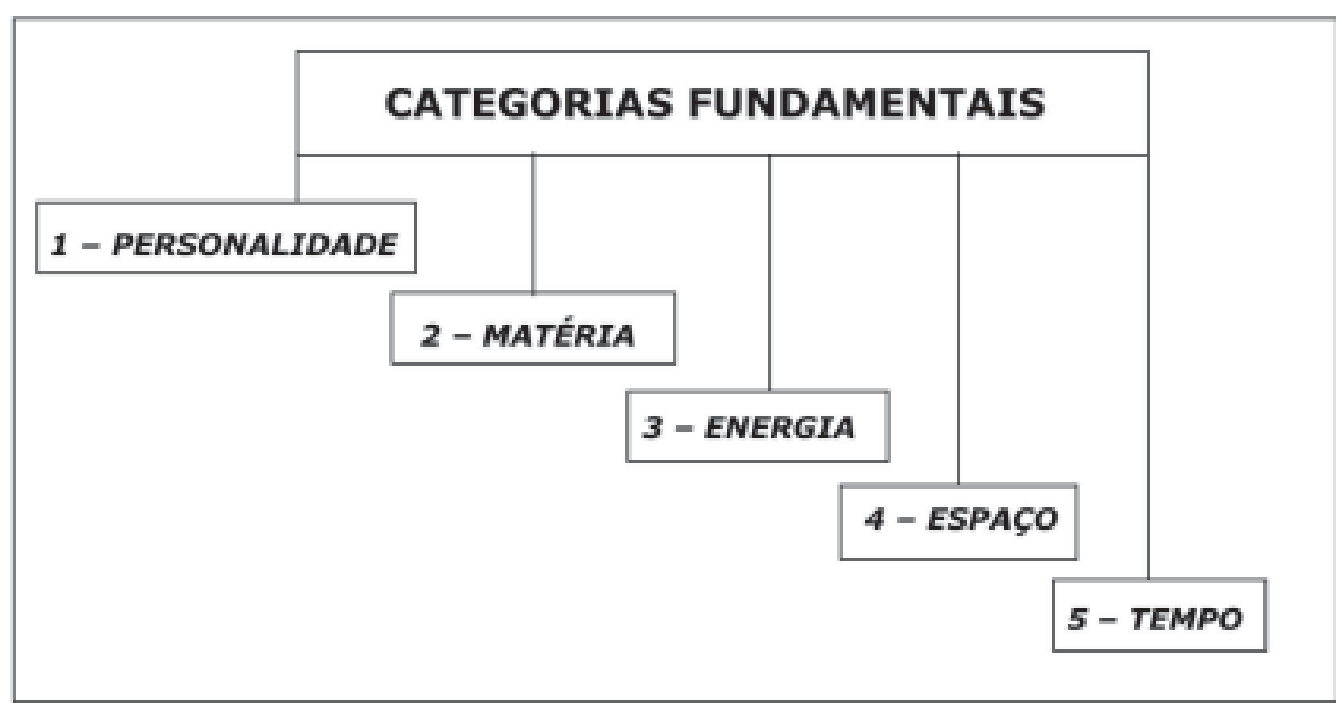


É importante ressaltar que Ranganathan inverte a estratégia de Aristóteles: enquanto o estagirita entendia que as demais categorias são derivadas e fazem referência à categoria da Substância, que é autoevidente, o indiano estabelece a categoria Personalidade como “indefinível”. Para o primeiro, como vimos, o que não é por si, ou seja, substância, é não por si, isto é, acidente e, portanto, incluído em alguma das demais categorias, segundo suas notas características. Ranganathan, em contraposição ao filósofo grego, concebe que, com a utilização do método residual,

[...] a manifestação da categoria fundamental 'Personalidade' é facilmente determinável por não ser de 'Tempo', de 'Espaço', de 'Energia' ou 'Matéria' [...] este é o método dos resíduos (1967, p. 401 - tradução nossa).

Ora, como o postulado das categorias fundamentais expressa que há cinco e somente cinco categorias fundamentais, toda manifestação que não recair sobre as outras quatro, mais facilmente determináveis, recairá sobre a categoria Personalidade. Entretanto, Ranganathan concede que, em alguns casos, tal determinação pode se revelar problemática, mas ela tende a se resolver com a prática e o consequente aumento da experiência na identificação dos assuntos suscetíveis de uma classificação bibliográfica.

\section{INTER-RELAÇÕES ENTRE OS SISTEMAS}

A identificação de conexões entre as concepções de categoria dos três pensadores estudados busca destacar a importância dos processos de organização e classificação do conhecimento e indicar as dificuldades inerentes desta tarefa. Em outras palavras, a plena realização dessa tarefa passa longe de ser algo trivial e corriqueiro, dependendo de critérios bem fundamentados, racionais e de um imenso trabalho intelectual. Foi exatamente para ilustrar essas afirmações que os sistemas categoriais foram apresentados e analisados. Tudo isso tendo em vista indicar a necessidade de valorizar o trabalho dos profissionais da informação envolvidos nas práticas de organizar e classificar o conhecimento.

O profissional da informação está envolvido com conhecimentos multidisciplinares em crescimento constante. Para suprir os novos desafios é essencial identificar aspectos de afinidades que as partes constituintes do conhecimento mantêm entre si. A estratégia do uso de categorias mostra-se capaz de suprir essa necessidade, conforme apresentado anteriormente. Foi essa razão que motivou a análise das diferentes concepções de categorias abordadas e o estabelecimento de inter-relações entre elas.

Os três sistemas de organização do conhecimento elegem as categoriais como elementos imprescindíveis e primordiais. As diferenças dizem respeito principalmente aos objetivos de cada sistema, ou seja, a formulação e o uso das categorias estão condicionados aos objetivos e finalidades de cada concepção intelectual. Entretanto, as categorias são colocadas sempre como princípios básicos que possibilitam identificar, classificar e organizar o conhecimento humano.

A apresentação dos sistemas categoriais indica que Aristóteles extrai suas categorias da própria realidade, da qual são a expressão mais geral, enquanto Kant deriva as suas da lógica formal, entendida como a estrutura do pensamento. Há uma diferença fundamental entre as duas concepções, pois o sentido aristotélico

É evidentemente muito diferente daquele que revestirá este termo com Kant. As categorias de Aristóteles não são conceitos a priori. Nem mesmo, de início, conceitos simplesmente pensados são conceitos postos em operação nos juízos. Muitos predicados convêm, de fato, a uma mesma realidade, mas não exprimem a mesma coisa de seu sujeito. É, evidentemente, diferente dizer que Sócrates, por exemplo, é um homem, ou dizer que ele é branco, afirmar que ele mede tantos côvados ou que ele é filho de Sofronisco, que está em Atenas etc. Os 
predicados de todos estes juízos não se unem da mesma maneira ao sujeito, eles representam modos de ser distintos. É classificando estes predicados diversos sob um pequeno número de títulos que Aristóteles obteve sua tabela das categorias (MANSION, 2005, p. 78).

As categorias aristotélicas também constituem princípios lógicos, mas são produto do pensamento em sua conjunção com a experiência. Assim, são preenchidas com atributos do ser.

Já as kantianas não têm conteúdo empírico porque se caracterizam como formas de raciocínio: são pura forma lógica sob as quais se podem produzir outros conceitos, no caso, os conceitos empíricos. Desta maneira, elas são formas sintetizadoras de conteúdos. Segundo o filósofo alemão:

O entendimento esgota-se totalmente nessas funções e a sua capacidade mede-se totalmente por elas. Chamaremos a estes conceitos categorias, como Aristóteles, já que o nosso propósito é, de início, idêntico ao seu, embora na execução dele se afaste consideravelmente (KANT, 1997, p. 108).

Ora, a reformulação por Kant se afasta da perspectiva aristotélica, porque, por si mesmas, as categorias kantianas são apenas funções lógicas, mas, em harmonia com a sensibilidade, tornam possíveis os juízos sobre a experiência. Portanto, todo conhecimento é derivado de princípios lógicos - no caso, as categorias - e das formas da linguagem expressas nos juízos que emitimos sobre as coisas.

Os juízos unificam o múltiplo, ao passo que as categorias são as unidades básicas através das quais esta unificação se processa. Elas são concebidas como contributos para a formação dos juízos: é partindo desta perspectiva que o filósofo alemão as formula para fornecerem um inventário exaustivo de como é possível conhecer, pois só mediante elas se "[...] pode compreender algo no diverso da intuição" (KANT, 1997, p. 111).
Como vimos, também é verdade que para Aristóteles as categorias estão relacionadas aos juízos, isto é, às formas como se fala das coisas. Entretanto, a diferença fundamental reside no fato de que para Kant o princípio que orienta a descoberta das categorias reside no sujeito cognoscente e nas suas capacidades cognitivas, enquanto para Aristóteles a descoberta se faz a partir da própria realidade, já que a linguagem é expressão fidelíssima dela, sendo as categorias operadas a partir do confronto com a realidade.

Kant reformula estes conceitos fundamentais explicitando que eles não se formam a partir do contato com a realidade, ou seja, não são produzidos pelos objetos da experiência, pois são independentes, apesar de deverem necessariamente concordar com tais objetos e, por consequência, concordar com a própria realidade. É por isto que são denominadas 'a prior', pois são operações do pensar humano que contêm todas as outras, permitindo colocar a multiplicidade das representações sob uma unidade do pensar. Esta unificação se dá por meio dos juízos que, com o auxílio das categorias, permitem referir às várias maneiras como a multiplicidade pode ser unificada.

Outra diferença fundamental está no fato de Kant, ao contrário de Aristóteles, não considerar o espaço e o tempo como categorias, mas como condições e pressupostos para o conhecimento dos seres com o auxílio delas. Kant concebe estas condições como princípios universais inerentes a toda e qualquer forma de experiência humana. Portanto, como vimos, o espaço e o tempo são considerados não como categorias, mas como condições fundamentais para a experiência.

Ranganathan, por seu turno, resgata as noções de espaço e de tempo para as formas categoriais, pois seu objetivo, assim como o do célebre estagirita, também é avaliar os objetos, segundo as características básicas deles - isto é, o que faz eles serem o que são - e suas relações fundamentais, como estar, permanecer, relacionar-se com outros ou mudar: 
As categorias de Aristóteles, retomadas com ligeiras alterações por Ranganathan e que propiciam a análise dos conceitos em ângulos diversos de abordagem, as facetas, têm sido consideradas por muitos como uma alternativa para a organização semântica (ALVARENGA, 2006, p. 97).

As categorias de Aristóteles e de Ranganathan são declaradamente ontológicas, ao passo que as kantianas são manifestações puramente lógicas, embora revelem fundamentos ontológicos. ${ }^{8}$ A perspectiva ontológica e a abordagem dos diversos aspectos que envolvem o ser exigem as noções de tempo e de espaço como fundamentais tanto para identificar objetos em geral quanto para a identificação dos assuntos que compõem um documento. Nos dois casos, a determinação espaço-temporal é tão comum quanto imprescindível.

O resgate do espaço e do tempo como formas categoriais distancia o pensador indiano de Kant, pois ele não pretende estabelecer as condições segundo as quais o conhecimento se processa na experiência humana. O objetivo primordial dele é a organização e a classificação do conhecimento registrado. Entretanto, a determinação desse objetivo também o afasta de Aristóteles, que pretende identificar e avaliar os objetos do mundo de maneira geral.

Ranganathan direciona o foco da sua investigação para os assuntos dos documentos e os métodos válidos para sua classificação e expressão linguística. A questão é que para disponibilizar

\footnotetext{
${ }^{8}$ Sob certos aspectos, as categorias kantianas também são ontológicas. É difícil efetuar uma separação precisa entre ontologia e epistemologia no sistema kantiano. Kant afirma que “[...] o orgulhoso nome de ontologia, que se arroga a pretensão de oferecer, em doutrina sistemática, conhecimentos a priori das coisas em si [...] tem de ser substituído pela mais modesta denominação de simples analítica do entendimento puro.". (KANT, 1997, p. $264-$ CRP, A 247, B 303). O ponto em questão revela apenas que, na abordagem kantiana, os princípios apresentados se aplicam apenas aos objetos da experiência humana, e não às coisas em geral. Assim, a sua 'Analítica Transcendental' também apresenta fundamentos ontológicos, mas em sentido restrito ao conhecimento humano.
}

informações organizadas não há outro caminho a não ser classificar o conteúdo do que se quer transmitir dentro de uma classe determinada que contenha um certo grupo de entidades. Este procedimento exige, necessariamente, uma generalização que se reflete nas formas categoriais, a partir das quais se podem identificar as particularidades de cada entidade analisada ao subsumi-la àqueles conceitos de larga aplicação.

As categorias ranganathianas buscam apreender as diversas perspectivas possíveis do conhecimento registrado por meio de ideias mais gerais, elementares e essenciais de que são constituídas. Para isto, partindo da categoria 'Personalidade', pode-se chegar a novas categorias que permitam identificar os diferentes aspectos e particularidades dos documentos, estruturando seus conteúdos e indo de conceitos fundamentais mais gerais para os mais específicos: desse modo, aumenta-se gradualmente a complexidade dos assuntos.

Ranganathan e Aristóteles procuram organizar o conhecimento do mundo partindo da própria realidade, buscando as classes mais gerais nas quais ele pode ser inicialmente classificado. Estas classes dão origem a novas classes que são, necessariamente, a posteriori, pois se revelam como produto da aplicação dos princípios primeiros às entidades analisadas.

As categorias de Ranganathan se constituem a partir da realidade, da observação e da experiência. Portanto, elas são categorias empíricas. Importante ressaltar que, mesmo relacionadas às categorias filosóficas ocidentais, o mestre indiano sofreu grande influência do pensamento oriental na sua concepção de conhecimento. O próprio hinduísmo e o budismo, filosofias de vida predominantes na Índia, apresentam categorias próprias para o desvelamento da realidade. Assim, é importante destacar que:

Para a classificação do conhecimento, Ranganathan adotou um estilo aforístico, aproximando-se do princípio de 'unidade do 
pensamento atômico'. Essa tendência deveuse exclusivamente à sua familiaridade com o pensamento indiano e com a literatura védica. Acredita-se que a gênese do seu pensar estava em sua visão holística do universo influenciada pelas culturas brâmane, chinesa e também pela astrologia (NAVES, 2006, p. 41).

É muito provável que a elaboração das categorias de Ranganathan tenha se orientado também por outras ideias não concebidas como princípios filosóficos. Entretanto, o objetivo deste trabalho foi apresentar as categorias e analisá-las segundo cada um dos autores escolhidos. Fica aqui a indicação dessas outras influências, no que diz respeito às categorias, para outros trabalhos relacionados ao tema que tenham em vista a perspectiva de concebê-las como fundamentos para a organização do conhecimento.

\section{CONCLUSÕES}

A apresentação das categorias à luz de três teorias distintas e a sua consequente interpretação buscou salientar a importância dos princípios fundamentais para a organização do conhecimento. Para tanto, foram abordados os trabalhos desenvolvidos por Aristóteles, Kant e Ranganathan no que se referem à noção de categoria e à função que desempenham em cada um dos sistemas destes pensadores.

Para cada um destes autores, as categorias foram identificadas como essenciais para a elaboração dos respectivos sistemas e para a elucidação de questões relativas ao conhecimento humano, seja de uma perspectiva que pretenda abarcar a totalidade da realidade, as condições da cognição humana ou mesmo o saber registrado em suas mais diferentes formas.

Aristóteles concebe as categorias como 'modos do ser', mas para Kant elas são 'modos de pensar'. Já Ranganathan as elabora como 'modos de classificar'. A explicitação e a interpretação destes diferentes modos funcionais buscaram justificar a hipótese inicial que salienta a importância das categorias como unidades cognitivas instrumentais essenciais para organização e classificação do conhecimento.

As três concepções as indicam como princípios fundamentais, ou seja, como formas lógicas que possibilitam atingir os objetivos estabelecidos por cada um dos pensadores no desenvolvimento dos seus respectivos trabalhos teóricos. O primeiro, Aristóteles, apresenta um estudo dos entes mais gerais da realidade, expresso na formulação de categorias através das quais podemos compreender as coisas que compõem o mundo. Já o segundo, Kant, indica que as categorias não podem ser elaboradas a partir das coisas, mas sim a partir da estrutura lógica do próprio pensamento. Por sua vez, Ranganathan as elabora com a função específica de permitir a identificação, a classificação e a organização dos registros produzidos pelos seres humanos.

Como foi visto, Aristóteles e Ranganathan formulam categorias que entram em operação a partir do confronto do pensamento com a experiência, buscando ordená-la, enquanto Kant elabora categorias puramente formais. As últimas correspondem a conceitos puros ou a priori, sendo que é através deles que se podem elaborar outros conceitos relacionados à experiência, ou seja, os conceitos empíricos.

Há duas classes de conceitos: os a priori, pura forma lógica do pensar, e os a posteriori, por entrarem em operação a partir do contato com a realidade e os objetos que a compõem, sendo, desta forma, empíricos. Os conceitos empíricos são extraídos da experiência e, portanto, a posteriori. Entretanto, o conceito empírico está submetido ao conceito puro, ou seja, o seu processo de constituição se efetiva mediante a comparação, reflexão e abstração oferecido pelas categorias. A diferença, como o trabalho indicou, é que os conceitos a priori se restringem à esfera do pensamento, ao passo que os conceitos a posteriori entram em operação a partir de uma experiência efetiva e com o auxílio dos conceitos puros oriundos da lógica.

Ci. Inf., Brasília, v. 38, n. 1, p. 86-108, jan./abr. 2009 
As categorias de Aristóteles e de Ranganathan funcionam como postulados que exercem a função de orientar o pensamento em confronto com a multiplicidade que se lhe apresenta, seja de objetos do mundo, como no caso do primeiro, seja de assuntos contidos em documentos, como é o caso do segundo. Portanto, são conceitos de alta generalidade e que originam novos conceitos.

Um conceito identifica traços semelhantes que se sobressaem, enquanto os casuais se diluem entre si. Os traços são ressaltados no momento em que coincidem entre si através da avaliação de características básicas que permitem efetuar o estabelecimento de relações, pois, ao se relacionarem as características de um objeto com outro, busca-se uma conexão entre eles. Aí então é possível conhecer e classificar os objetos. É por esta razão que a teoria das categorias, sejam elas concebidas como princípios puramente lógicos ou ontológicos, revela-se como essencial ao estudo e à aplicação da classificação. Ao indicar que classificar e organizar pressupõe unidades mínimas de sentido, o trabalho ressaltou que o reconhecimento da importância de uma teoria das categorias se mostra, ainda hoje, capaz de lançar luz sobre problemas enfrentados pelos profissionais da informação.

A fundamentação das categorias elaborada por Ranganathan indica caminhos para que o profissional da informação encontre subsídios coerentes e consistentes no sentido de efetuar uma classificação com qualidade, eficácia e eficiência. Por seu turno, a elaboração aristotélica permite a este profissional ter uma visão ampla da classificação do conhecimento e das dificuldades inerentes a ela. A reflexão sobre o levantamento de problemas filosóficos referentes às formas de se falar das coisas do mundo e às soluções propostas pelo filósofo grego pode ser de grande valia para o classificador que pretenda aprofundar conhecimentos e, consequentemente, melhorar suas práticas. Também a contribuição kantiana é de suma importância, pois indica a relevância de uma abordagem epistemológica sobre o processo de constituição do pensamento humano.
Os textos de Kant e Aristóteles que envolvem as categorias apresentam muito mais sutilezas e complexidade do que este trabalho pretendeu mostrar. Entretanto, reconhecendo a importância destes textos e a relevância deles para a teoria da classificação, permitiu-se aqui efetuar recortes de pontos considerados fundamentais para estabelecer relações com as ideias de Ranganathan. Apesar da dificuldade inerente aos assuntos tratados, esperase ter contribuído de alguma forma para uma reflexão sobre a temática abordada.

Artigo submetido em 01/11/2008 e aceito em 11/05/2009.

\section{REFERÊNCIAS}

ABBAGNANO. Nicola. Diccionário de filosofía. 2. ed. México: Fondo de Cultura Económica, 1974.

História da filosofia: Berckeley, Hume, o iluminismo inglês, francês, italiano e alemão, Kant. 4. ed. Lisboa: Presença, 1994. $8 \mathrm{v}$.

ALVARENGA, Lídia. Organização da informação nas bibliotecas digitais. In: NAVES, Madalena Martins Lopes; KURAMOTO, Hélio (Org.). Organiz̧ação da informação: princípios e tendências. Brasília: Briquet de Lemos, 2006. p. 76-98.

ARISTÓTELES. Metafísica. Edição trilingue - grego, latim e espanhol de Valentín García Yebra. Madrid: Gredos, 1998.

ARISTOTLE. Categories. In: Princeton University Press, 1995. p. 3-24.

BITTAR, Eduardo Carlos Bianca. Curso de filosofia aristotélica: leitura e interpretação do pensamento aristotélico. Barueri: Manole, 2003.

BOCK, Ana Mercês Bahia; FURTADO, Odair; TEIXEIRA, Maria de Lourdes Trassi. Psicologias: uma introdução ao estudo de psicologia. 13. ed. São Paulo: Saraiva, 1999. 117 p.

CAMPOS, Maria Luiza de Almeida. Linguagens documentárias: teorias que fundamentam sua elaboração. Niterói: UDUFF, 2001.

CASSIRER, Ernst. Ensaio sobre o homem: introdução a uma filosofia da cultura humana. São Paulo: Martins Fontes, 1994.

Linguagem e mito. São Paulo: Perspectiva, 1992.

CAUQUELIN, Anne. Aristóteles. Rio de Janeiro: Jorge Zahar, 1995.

CAYGILL, Howard. Dicionário Kant. Rio de Janeiro: Jorge Zahar, 2000 a.

Kant e a "Época da crítica". In: - Dicionário

Kant. Rio de Janeiro: Jorge Zahar, 2000b. p. 19-40. 


\section{Michel Maya Aranalde}

DRISCOLL, J. A. Êide (EIÄH) nas teorias da substância de juventude e de maturidade de Aristóteles. In: ZINGANO, Marco Antônio de Ávila (Coord.). Sobre a metafísica de Aristóteles: textos selecionados. São Paulo: Odysseus, 2005. p. 281-313.

FONSECA, Eduardo Giannetti da. Por que ler Aristóteles hoje?. Revista Entre Livros, São Paulo, n. 1, p. 80-83, 2005. Edição Especial 'Grécia em Cena: primeiras letras em verso e prosa'.

FOSKETT, Antony Charles. A abordagem temática da informação. São Paulo: Polígono; Brasília: Ed. Universidade de Brasília, 1973.

KANT, Immanuel. Crítica da Razão Pura. 4. ed. Lisboa: Calouste Gulbenkian, 1997.

70, 2003.

Prolegômenos a toda metafísica futura. Lisboa: Edições

MANSION, Suzanne. A primeira doutrina da substância: a substância segundo Aristóteles. In: ZINGANO, Marco Antônio de Ávila (Coord.). Sobre a metafísica de Aristóteles: textos selecionados. São Paulo: Odysseus, 2005. p. 73-92.

NAVES, Madalena Martins Lopes. A importância de Ranganathan para a organização do conhecimento. In: NAVES, Madalena Martins Lopes; KURAMOTO, Hélio (Org.). Organização da informação: princípios e tendências. Brasília: Briquet de Lemos, 2006. p. 36-45.

PELLEGRIN, Pierre. De Aristóteles a Tomás de Aquino. Scientific American Brasil, São Paulo, n. 10, p. 16-19, 2006. Edição Especial 'Gênios da Ciência'.
RANGANATHAN, Shiyali Rumamrita. Colon Classification. Madras: Madras Library Association, 1957.

Prolegomena to library classification. 3rd ed. Bombay: Asia Publishing House, 1967.

SHERA, Jesse Hauk. Catálogo sistemático: princípios básicos e utilização. Brasília: Universidade de Brasília, 1969.

SOUZA, Francisco das Chagas de. Organização do conbecimento na sociedade. Florianópolis: UFSC, 1998.

TORRETTI, Roberto. Immanuel Kant: estudio sobre los fundamentos de la filosofia crítica. Santiago: Universidad del Chile, 1967.

VICKERY, Brian C. Classificação e indexação nas ciências. Rio de Janeiro: BNG, 1980

XIAO, Yan. Faceted classification: a consideration of its features as a paradigm of knowledge organization. Knowledge Organization, v. 21, n. 2, p. 64-68, 1994.

ZINGANO, Marco Antonio de Ávila. Nasce a filosofia. Revista Entre Livros, São Paulo, n. 1, p. 66-73, 2005. Edição Especial 'Grécia em Cena: primeiras letras em verso e prosa'.

Platão e Aristóteles: os caminhos do conhecimento. São Paulo: Odysseus, 2002. 